\title{
Trade Complementarity and Competitive Analysis between China and Countries under "the Belt and Road" Initiative
}

\author{
Pei-Zhi WANG ${ }^{1, a}$, Ling-Xi CHU ${ }^{1, b,{ }^{*}}$, Yu-Xin ZHAO ${ }^{1, c}$ \\ ${ }^{1}$ Shandong University of Finance and Economics, Jinan, China \\ awpzmail@126.com, bclx0459@163.com, ${ }^{\mathrm{a}} 723797175 @ q q . c o m$
}

Keywords: Comparative advantage, Trade complementarity index, Trade competitiveness index.

\begin{abstract}
Since the "Belt and Road Initiative" was put forward, it has played an important role in the economic and trade exchanges between various countries and in the development of the world economy. Based on the theory of comparative advantage, this paper studies the basic trade situation between China and the Belt and Road countries represented by Russia and India. By means of dominant comparative advantage index (RCA), trade complementarity index (TCI) And other indicators, analyzed in detail the trade competitiveness and complementarities between China and India and Russia, clarified the degree of trade competition and interdependence between China and the world in the world market so as to explore more favorable trade structure and trade Development methods.
\end{abstract}

\section{Introduction}

The construction of "One Belt and One Road" follows the tide of multipolarization, economic globalization and social informatization in the world pattern and is conducive to the construction of an open world economy and a free trade system. Since 2001, the trade between China and the countries along the "One Belt and One Road" has been growing rapidly. Especially since 2008, the trade between China and the countries along the "Belt and Road" has entered a period of rapid development. The total volume of trade between the two countries along the "Belt and Road" has dropped from 84 in 2001 The amount of 100 million U.S. dollars increased to 953.59 billion yuan in 2016. Accounting for $25.7 \%$ of the total trade volume between China and the world.From the figures of countries and global trade along the "Belt and Road" in 2016, the total foreign trade volume of India and Russia ranks the world's second and third respectively. From the perspective of exports, Russia has the highest level of foreign exports while that of India and India accounts for the highest. Russia and China both belong to emerging economies. Moreover, they are close to China's geographical location and have close political relations with good foundation and advantages in economic and trade cooperation with China. Therefore, Russia is selected as the representative of developed countries for comparative analysis. China and India are also geographically adjacent big powers. Historically, India has played a very crucial role in both the ancient North and South Silk Roads. In the new "One Belt and One Road" strategy, India has the same status Therefore, India is selected as the representative of Asian developing countries along the Belt and Road initiative.

The innovation of this paper lies in the empirical analysis of the trade patterns between China and India and Russia in the past ten years through the empirical analysis of the trade data between China and the two countries. It is more comprehensive and objective and enables the research process and results of this article More persuasive, but also provide a more solid reference for policy recommendations. However, there are still many shortcomings: because of the author's ability, although India and Russia are selected as representatives of Asia-Europe developing countries and developed countries, only the two countries can not fully represent and sum up the countries along the Belt and Road Situation, persuasion is not strong enough. I hope in the future research can do detailed and detailed portrayal. 


\section{Literature Review}

According to the existing research, there are many articles on the orientation, development trend, spatial layout and the trade pattern between China and some countries or regional economic organizations. However, There is relatively little literature on the competitive complementarities of major countries. And most of these related researches are generalized. They only describe the competitiveness and complementarity of the trade between China and India and China and Russia. This result lacks theoretical and empirical evidence. Most of the existing researches are only studied from one aspect of complementarity or competition. This paper argues that the study of Sino-Indian trade should be comprehensively considered both in complementarity and competitiveness. Products that are complementary should exert their comparative advantages while cultivating their competitive advantages. Competitive products, in cultivating their competition The same time, we can not ignore its comparative advantage.

\section{The Basic Situation of Trade between China and the Two Countries}

Trade scale:Since the 21st century, the bilateral trade between China and India has been accelerating at an ever-increasing pace and the trade relations have become increasingly close. Both China and India are extremely important trading partners for each other.

By the beginning of the 21st century, the volume of trade increased from 29.14 billion U.S. dollars in 2000 to 61.76 billion U.S. dollars in 2010, and the volume of bilateral trade between India and China reached 69.62 billion U.S. dollars by 2016. According to the statistics of India's Commercial Information Bureau and India According to the statistics of the Ministry of Commerce, the import and export volume of bilateral goods between India and China in 2016 was 69.62 billion U.S. dollars, down 1.7\%. Among them, India's exports to China hit 8.96 billion U.S. dollars, down 7.7 percent; its imports from China amounted to 60.66 billion U.S. dollars, down 0.8 percent. Trade deficit between India and China is 51.69 billion U.S. dollars. It can be seen from this that both China and India are very important trading partners for each other in terms of total import and export trade or trade.

For a long time, both China and Russia have maintained a stable neighborly and friendly relationship and bilateral trade between the two countries has developed rapidly. Now China has become Russia's largest importer and the second largest export market. Data show that in 2016, the total volume of bilateral imports and exports of China and Russia reached 66.11 billion U.S. dollars, an increase of nearly 4\%. According to Russian customs statistics, in 2016, the bilateral import and export of goods between China and Russia was 66.11 billion U.S. dollars, up 4.0\%. Among them, Russia exported 28.02 billion U.S. dollars to China, a decrease of $2.0 \%$, accounting for $9.8 \%$ of Russia's total exports. Russia imported 38.09 billion U.S. dollars from China, an increase of 9.0\%, accounting for $20.9 \%$ of Russia's total imports. Russia's deficit was 10.07 billion U.S. dollars, up $58.6 \%$.

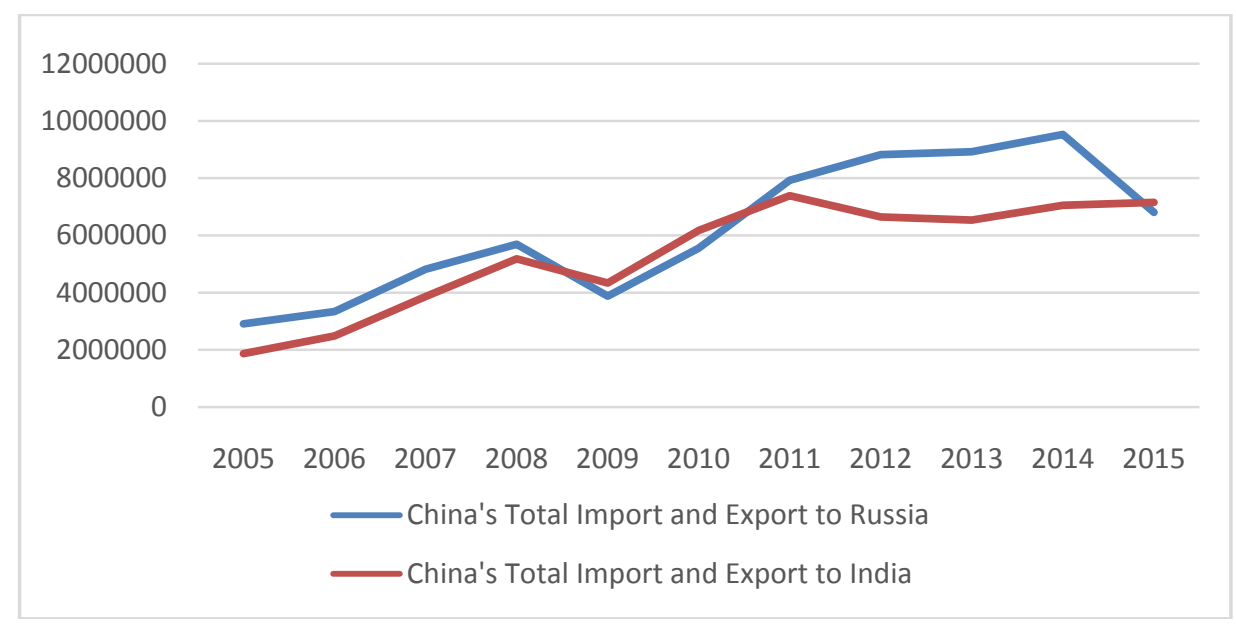

Fig.1 
Trade Structure: India imported mainly from manufactured products and semi-finished products such as electromechanical products, base metals and products, and chemical products. Imports from China amounted to USD31.66 billion, USD93.1 million and USD4.34 billion respectively in 2016, Textile and raw materials and chemical products increased by $7.5 \%$, chemical products and base metals and products decreased by $21.6 \%$ and $18.6 \%$, accounting for $52.2 \%, 15.4 \%$ and $7.2 \%$ of India's total imports from China. India imported more transportation equipment from China to achieve more substantial growth, an increase of 47.6\%. , Labor-intensive products accounted for a smaller proportion. However, the primary products such as minerals, textiles, raw materials and chemical products occupy the vast majority of India's exports to China, mainly labor-intensive and resource-intensive products. India's trade surplus with China is larger. Among them, the export of mineral products, textiles, raw materials and chemical products in 2016 were respectively 2.38 billion U.S. dollars, 1.58 billion U.S. dollars and 1.26 billion U.S. dollars, mineral products increased by $41.3 \%$, textiles and raw materials and chemical products decreased by $30.5 \%$ and $12.6 \%$ Exports to China $26.6 \%, 17.6 \%$ and $14.1 \%$ of the total.

Russia imports the main commodities from China for the mechanical and electrical products, textiles and raw materials and base metals and products are mainly high value-added finished products, the proportion of primary products is relatively small. Exports of the three categories of products accounted for $68.3 \%, 9.5 \%$ and $5.1 \%$ of Russia's total exports respectively in 2016 with exports of US \$ 18.7 billion, 2.59 billion U.S. dollars and 1.39 billion U.S. dollars respectively, a decrease of $5.2 \%$ and an increase of $17.0 \%$ A decrease of $11.4 \%$. However, the products exported by Russia to China are energy-intensive, with a larger quantity of mineral products, wood products and electromechanical products. Exports of the three categories of products accounted for 68.3\%, 9.5\% and 5.1\% of Russia's total exports respectively in 2016 with exports of US \$ 18.7 billion, 2.59 billion U.S. dollars and 1.39 billion U.S. dollars respectively, a decrease of 5.2\% and an increase of $17.0 \% \mathrm{~A}$ decrease of $11.4 \%$. In 2016, the fastest-growing Russian exports to China were transportation equipment, an increase of $267.3 \%$, followed by precious metals and products, an increase of $125.4 \%$. Base metal and products declined more, down $44.8 \%$.

\section{Trade Competitiveness Analysis}

RCA is a widely used method of measuring the comparative advantages of economies in international trade.According to Balassa's (1965) study, the RCA index can be used to analyze the specialization patterns of production and trade, reflecting the level of competitiveness and specialization of the country in the export trade.

Eq. $1 R A_{k a}=(X i k X i) /(X w k X w)$

Table1. RCA of Chinese exports

\begin{tabular}{|l|l|l|l|l|l|l|l|l|l|l|l|}
\hline \multirow{2}{*}{ year } & \multicolumn{3}{|l}{ primary product } & \multicolumn{4}{|l|}{$\begin{array}{l}\text { Labor-intensive } \\
\text { finished goods }\end{array}$} & \multicolumn{2}{l|}{$\begin{array}{l}\text { Capitaland } \\
\text { technology-intensive } \\
\text { manufactured goods }\end{array}$} \\
\cline { 2 - 12 } & SITC0 & SITC1 & SITC2 & SITC3 & SITC4 & SITC6 & SITC8 & SITC5 & SITC7 & SITC9 \\
\hline 2007 & 0.49 & 0.14 & 0.23 & 0.17 & 0.10 & 1.23 & 2.15 & 0.43 & 1.21 & 0.04 \\
\hline 2008 & 0.42 & 0.13 & 0.23 & 0.16 & 0.12 & 1.32 & 2.17 & 0.51 & 1.31 & 0.03 \\
\hline 2009 & 0.43 & 0.15 & 0.20 & 0.15 & 0.07 & 1.20 & 2.07 & 0.43 & 1.39 & 0.03 \\
\hline 2010 & 0.45 & 0.15 & 0.18 & 0.13 & 0.05 & 1.21 & 2.12 & 0.49 & 1.41 & 0.02 \\
\hline 2011 & 0.46 & 0.16 & 0.18 & 0.11 & 0.05 & 1.28 & 2.23 & 0.55 & 1.44 & 0.03 \\
\hline 2012 & 0.43 & 0.16 & 0.17 & 0.10 & 0.05 & 1.30 & 2.32 & 0.52 & 1.42 & 0.01 \\
\hline 2013 & 0.41 & 0.15 & 0.17 & 0.10 & 0.05 & 1.34 & 2.33 & 0.51 & 1.43 & 0.01 \\
\hline 2014 & 0.40 & 0.15 & 0.18 & 0.10 & 0.06 & 1.37 & 2.25 & 0.53 & 1.35 & 0.02 \\
\hline 2015 & 0.40 & 0.17 & 0.18 & 0.12 & 0.06 & 1.37 & 2.02 & 0.51 & 1.28 & 0.02 \\
\hline 2016 & 0.45 & 0.19 & 0.18 & 0.15 & 0.05 & 1.36 & 2.01 & 0.51 & 1.25 & 0.04 \\
\hline
\end{tabular}


Calculating from the table1 we can clearly draw: China has comparative advantages in the three categories of SITC6, SITC7 and SITC8 (RCA> 0.8). The labor-intensive manufactured goods SITC6 has an RCA value of 1.20-1.37 and the SITC8 has an RCA value of 2.01-2.33. The RCA values of SITC7, which are capital or technology-intensive manufactured goods, range from 1.21 to 1.44, all in a highly competitive trade type.At present, China's competitiveness in manufacturing industry is more prominent. At the same time, its import dependence on related resources is also relatively large. This is precisely the current trade situation in China as a "world factory."

Table2 RCA of Russian exports

\begin{tabular}{|l|l|l|l|l|l|l|l|l|l|l|l|}
\hline \multirow{2}{*}{ year } & \multicolumn{4}{|l}{ primary product } & \multicolumn{4}{l|}{$\begin{array}{l}\text { Labor-intensive } \\
\text { finished goods }\end{array}$} & \multicolumn{2}{l|}{$\begin{array}{l}\text { Capitaland technology-intensive } \\
\text { manufactured goods }\end{array}$} \\
\cline { 2 - 12 } & SITC0 & SITC1 & SITC2 & SITC3 & SITC4 & SITC6 & SITC8 & SITC5 & SITC7 & SITC9 \\
\hline 2007 & 0.40 & 0.24 & 1.27 & 6.18 & 0.57 & 1.05 & 0.06 & 0.36 & 0.10 & 1.94 \\
\hline 2008 & 0.26 & 0.24 & 1.03 & 4.81 & 0.50 & 0.87 & 0.06 & 0.44 & 0.09 & 1.77 \\
\hline 2009 & 0.40 & 0.29 & 0.90 & 5.44 & 0.65 & 0.96 & 0.06 & 0.35 & 0.10 & 1.88 \\
\hline 2010 & 0.27 & 0.20 & 0.76 & 4.94 & 0.30 & 0.86 & 0.05 & 0.36 & 0.08 & 2.27 \\
\hline 2011 & 0.31 & 0.19 & 0.75 & 4.19 & 0.32 & 0.74 & 0.04 & 0.38 & 0.07 & 2.40 \\
\hline 2012 & 0.43 & 0.28 & 0.78 & 4.53 & 0.71 & 0.87 & 0.08 & 0.44 & 0.11 & 0.61 \\
\hline 2013 & 0.40 & 0.30 & 0.78 & 4.43 & 0.77 & 0.83 & 0.10 & 0.42 & 0.12 & 0.61 \\
\hline 2014 & 0.49 & 0.32 & 0.85 & 4.66 & 0.88 & 0.85 & 0.11 & 0.44 & 0.12 & 0.60 \\
\hline 2015 & 0.59 & 0.40 & 1.03 & 6.31 & 1.03 & 1.00 & 0.13 & 0.52 & 0.15 & 0.62 \\
\hline 2016 & 0.71 & 0.44 & 1.24 & 5.51 & 1.45 & 1.19 & 0.11 & 0.48 & 0.14 & 2.54 \\
\hline
\end{tabular}

Russia has a comparative advantage of products concentrated in the SITC 2 non-edible raw materials; SITC 3 fossil fuels and related raw materials, SITC6, SITC9 four products. The resource-intensive primary product SITC3 has an RCA value of about 4.19-6.31 and a strong trade competitiveness. The RCA value of the labor-intensive product SITC6 is about 1.1, and the trade competitiveness is average.

Russia is rich in natural resources and reserves of energy and mineral resources are very impressive. Its industrial development has a long history, its heavy industry is developed and its strength is strong. On the other hand, although Russia has a vast territory and a large part of its territory is in the sub-arctic and boreal regions, it has restricted the country's agricultural development and has a weak light industrial base. And Russia is sparsely populated, with a low labor force and labor costs. Therefore, SITC7 and SITC8 two products on the competitiveness of relatively weak. This situation is somewhat complementary to the relatively weak pattern of China's light industry, manufacturing industry and heavy industry. At the same time, China and Russia are both representatives of emerging economies. Many industries have relatively similar levels of development. Therefore, the two countries are still competitive in industrial development.

Table3 RCA of Indian exports

\begin{tabular}{|l|l|l|l|l|l|l|l|l|l|l|}
\hline \multirow{2}{*}{ year } & \multicolumn{3}{|l|}{ primary product } & \multicolumn{2}{l|}{$\begin{array}{l}\text { Labor-intensive } \\
\text { finished goods }\end{array}$} & \multicolumn{2}{l|}{$\begin{array}{l}\text { Capitaland technology-intensive } \\
\text { manufactured goods }\end{array}$} \\
\cline { 2 - 12 } & SITC0 & SITC1 & SITC2 & SITC3 & SITC4 & SITC6 & SITC8 & SITC5 & SITC7 & SITC9 \\
\hline 2007 & 1.58 & 0.44 & 2.10 & 1.25 & 0.67 & 2.05 & 1.31 & 1.06 & 0.31 & 0.27 \\
\hline 2008 & 1.64 & 0.57 & 1.89 & 1.09 & 0.62 & 1.20 & 1.16 & 1.08 & 0.40 & 0.34 \\
\hline 2009 & 1.08 & 0.64 & 1.63 & 1.02 & 0.63 & 1.97 & 1.55 & 0.91 & 0.45 & 0.76 \\
\hline 2010 & 1.22 & 0.58 & 1.71 & 1.19 & 0.66 & 2.19 & 1.13 & 0.97 & 0.42 & 0.39 \\
\hline 2011 & 1.32 & 0.42 & 1.23 & 1.16 & 0.62 & 1.92 & 1.24 & 0.96 & 0.43 & 0.91 \\
\hline 2012 & 1.57 & 0.49 & 1.57 & 1.14 & 0.58 & 1.87 & 1.35 & 1.11 & 0.42 & 0.18 \\
\hline 2013 & 1.63 & 0.49 & 1.18 & 1.28 & 0.61 & 2.02 & 1.03 & 1.10 & 0.42 & 0.42 \\
\hline 2014 & 1.59 & 0.46 & 1.04 & 1.47 & 0.59 & 1.91 & 1.12 & 1.10 & 0.45 & 0.20 \\
\hline 2015 & 1.53 & 0.47 & 1.31 & 1.16 & 0.61 & 1.36 & 1.18 & 1.03 & 0.49 & 0.25 \\
\hline 2016 & 1.38 & 0.50 & 1.07 & 1.36 & 0.62 & 1.38 & 1.11 & 1.12 & 0.32 & 0.21 \\
\hline
\end{tabular}


As can be seen from the analysis and comparison of the RCA values mentioned above, apart from India and China in the fields of machinery, transportation equipment, beverages and tobacco, which have strong complementarities between India and China, India has considerable competitive advantages among other industries. However, its difference with China still exists. Our country is more competitive in finished products while India is more competitive in the raw material industry. Compared with India, China's advantages in primary products are not obvious. Instead, India has comparative advantages such as SITC0-3. This shows that China and India have strong complementarities in primary products. In labor-intensive products such as SITC6 and SITC8, both countries have strong comparative advantages. In SITC6, India has stronger advantages than China. On SITC8, China has stronger advantages than India and India has a stronger comparative advantage in such products The comparative advantage is weakened, indicating that there is fierce competition between China and India on labor-intensive products, but the intensity has been eased. China and India each have different competitiveness in capital and technology-intensive products. China's RCA value is less than 1 on SITC5 goods, while India's RCA value is greater than 1; on China's SITC7 goods, China's RCA value is more than 1, India's RCA is less than one. This shows that China and India have their respective advantages in capital and technology-intensive products, and there is some complementarity.

\section{Trade Complementarity Analysis}

TCI can comprehensively measure the degree of trade complementarity among different countries and can make a comprehensive measurement of the comparative advantages among different countries and regions from the aspects of export advantages and export advantages. TCI is a more comprehensive index that examines the degree of trade complementarity among countries in different regions. It was first proposed by economist Bitter Drags. The formula is:

$$
\text { TCIkij=RCAkxi*RCAkmj, RCAkmj=(Mkj/Mj)/(Xkw/Xw) }
$$

TCI> 1, indicating that the two countries have strong complementarities in such products. The larger the TCI index, the stronger the trade complementarities between the two countries. The calculated comparative disadvantage indices for the three countries are as follows:

Table 4 TCI -China exports to Russia

\begin{tabular}{|l|l|l|l|l|l|l|l|l|l|l|}
\hline \multirow{2}{*}{ year } & \multicolumn{4}{|l|}{ primary product } & \multicolumn{4}{l|}{$\begin{array}{l}\text { Labor-intensive } \\
\text { finished goods }\end{array}$} & \multicolumn{2}{l|}{$\begin{array}{l}\text { Capitaland technology-intensive } \\
\text { manufactured goods }\end{array}$} \\
\cline { 2 - 12 } & SITC0 & SITC1 & SITC2 & SITC3 & SITC4 & SITC6 & SITC8 & SITC5 & SITC7 & SITC9 \\
\hline 2007 & 1.06 & 0.28 & 0.16 & 0.02 & 0.16 & 1.13 & 1.60 & 0.42 & 1.53 & 0.07 \\
\hline 2008 & 0.77 & 0.26 & 0.16 & 0.01 & 0.17 & 1.16 & 1.81 & 0.48 & 1.86 & 0.03 \\
\hline 2009 & 0.94 & 0.30 & 0.16 & 0.01 & 0.10 & 1.14 & 1.82 & 0.48 & 1.52 & 0.05 \\
\hline 2010 & 0.96 & 0.30 & 0.09 & 0.01 & 0.06 & 1.16 & 2.13 & 0.54 & 1.59 & 0.04 \\
\hline 2011 & 0.83 & 0.27 & 0.08 & 0.01 & 0.05 & 1.19 & 2.17 & 0.56 & 1.85 & 0.07 \\
\hline 2012 & 0.81 & 0.29 & 0.11 & 0.01 & 0.05 & 1.42 & 2.65 & 0.56 & 2.02 & 0.00 \\
\hline 2013 & 0.81 & 0.28 & 0.11 & 0.01 & 0.05 & 1.46 & 2.73 & 0.58 & 1.94 & 0.00 \\
\hline 2014 & 0.76 & 0.29 & 0.13 & 0.01 & 0.05 & 1.43 & 2.56 & 0.61 & 1.75 & 0.00 \\
\hline 2015 & 0.72 & 0.33 & 0.17 & 0.02 & 0.07 & 1.38 & 2.02 & 0.65 & 1.45 & 0.00 \\
\hline 2016 & 0.72 & 0.36 & 0.17 & 0.01 & 0.06 & 1.38 & 1.92 & 0.64 & 1.36 & 0.03 \\
\hline
\end{tabular}




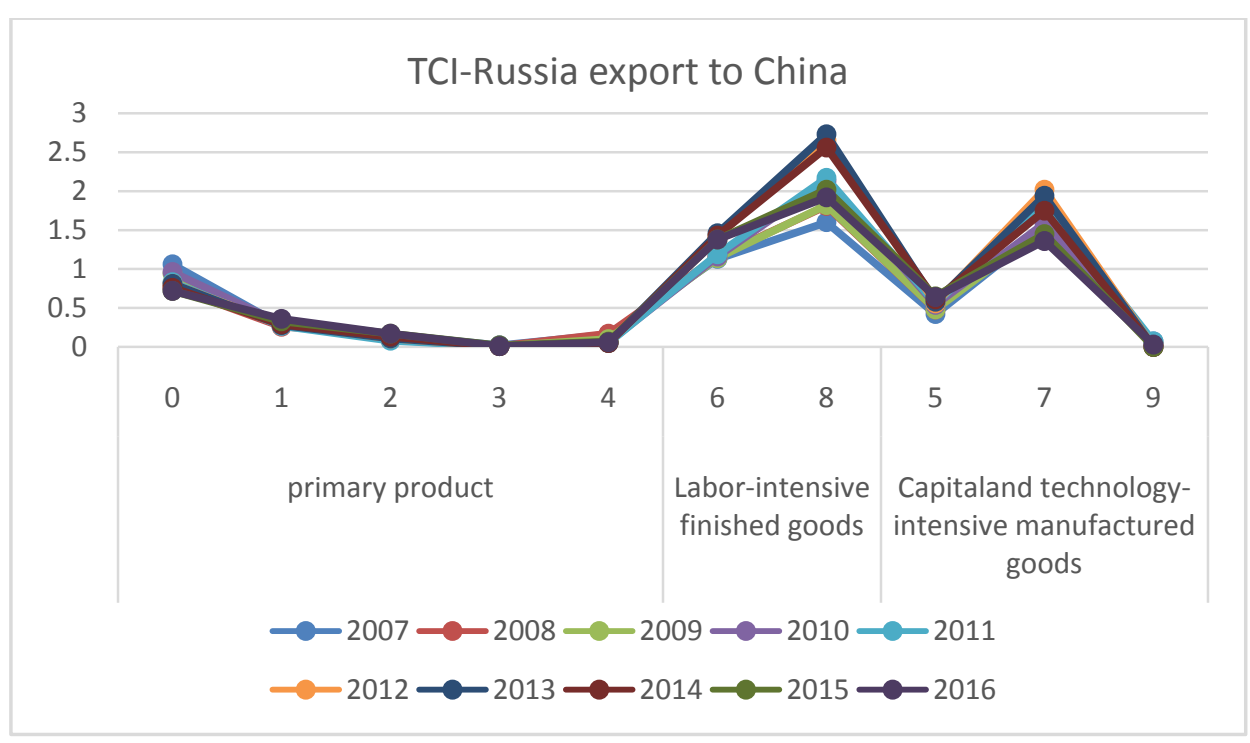

Fig2

As can be seen from the table4 and the Fig2, when China is an exporting country and Russia is an importing country, the two countries have some complementarity on SITC0, but the complementarity is not very strong. While the trade complementarity index on SITC1-SITC4 and SITC9 is very low, which shows that Russia and China are very weak in trade complementariness in the four categories of products as exporting countries; the SITC5-type products on both countries The trade complementarity is not high but its complementarity is continuously improving from 2007 to 2016 . When China is an exporter, the trade complementarities between the two countries in the finished products of SITC6, SITC7 and SITC8 are very strong. SITC6 and SITC8 are mainly labor-intensive manufactures and SITC7 is mainly capital-technology-intensive finished goods, which is in line with the superiority of Chinese manufactured products over that of Russia. At the same time, it can be analyzed that China and Russia are constantly adjusting their bilateral trade structure and focusing on the trade in machinery and transportation equipment.

Table 5 TCI -Russia exports to China

\begin{tabular}{|l|l|l|l|l|l|l|l|l|l|l|}
\hline \multirow{2}{*}{ year } & \multicolumn{4}{|l|}{ primary product } & \multicolumn{4}{l}{$\begin{array}{l}\text { Labor-intensive } \\
\text { finished goods }\end{array}$} & \multicolumn{2}{l|}{$\begin{array}{l}\text { Capitaland technology-intensive } \\
\text { manufactured goods }\end{array}$} \\
\cline { 2 - 12 } & SITC0 & SITC1 & SITC2 & SITC3 & SITC4 & SITC6 & SITC8 & SITC5 & SITC7 & SITC9 \\
\hline 2007 & 0.10 & 0.04 & 3.87 & 4.96 & 1.29 & 0.82 & 0.05 & 0.38 & 0.11 & 0.14 \\
\hline 2008 & 0.06 & 0.05 & 3.63 & 4.25 & 0.97 & 0.62 & 0.05 & 0.43 & 0.11 & 0.17 \\
\hline 2009 & 0.10 & 0.06 & 3.25 & 4.66 & 1.01 & 0.85 & 0.05 & 0.32 & 0.12 & 0.14 \\
\hline 2010 & 0.08 & 0.04 & 2.55 & 4.31 & 0.40 & 0.65 & 0.04 & 0.33 & 0.09 & 0.80 \\
\hline 2011 & 0.09 & 0.05 & 2.51 & 3.73 & 0.38 & 0.51 & 0.03 & 0.35 & 0.08 & 1.94 \\
\hline 2012 & 0.15 & 0.09 & 2.56 & 4.27 & 0.95 & 0.59 & 0.06 & 0.39 & 0.12 & 0.51 \\
\hline 2013 & 0.15 & 0.09 & 2.59 & 4.10 & 0.88 & 0.54 & 0.07 & 0.36 & 0.14 & 0.70 \\
\hline 2014 & 0.20 & 0.11 & 2.74 & 4.65 & 0.90 & 0.62 & 0.07 & 0.38 & 0.13 & 0.65 \\
\hline 2015 & 0.28 & 0.17 & 3.23 & 6.63 & 1.00 & 0.66 & 0.09 & 0.45 & 0.16 & 0.68 \\
\hline 2016 & 0.35 & 0.19 & 4.16 & 6.39 & 1.35 & 0.79 & 0.07 & 0.42 & 0.15 & 2.38 \\
\hline
\end{tabular}




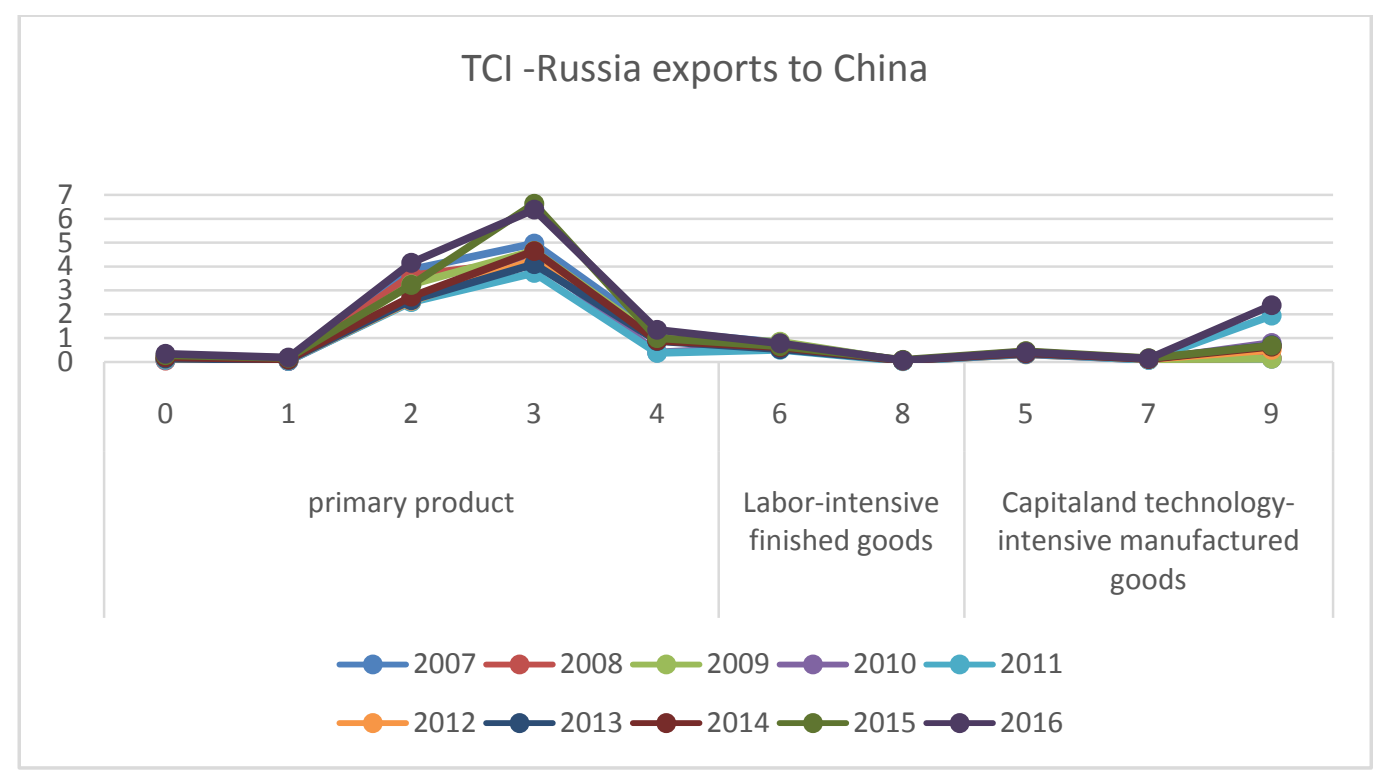

Fig3

When Russia is the exporting country and China is the importing country, the TCI index of the primary products SITC2, SITC3 and SITC4 is very high, which shows that the trade of the primary products between the two countries is very strong. And the complementary of SITC3, SITC4 and SITC9 While the SITC6, SITC7, SITC8 manufactures, the trade complementarity index between the two countries is very low, indicating that Russia exports to China are still products such as oil, natural gas and other primary sources of energy and fossil fuels are mostly, China is dependent on these resources of Russia, which is also in line with China's huge energy demand. And, from 2007 to 2016 ten years, there are changes in the indicators of trade complementarity but the changes are not very clear, indicating that the trade complementarity between China and Russia has long been relatively stable.

Table 6 TCI -China exports to India

\begin{tabular}{|l|l|l|l|l|l|l|l|l|l|l|}
\hline \multirow{2}{*}{ year } & \multicolumn{4}{|l|}{ primary product } & \multicolumn{3}{l}{$\begin{array}{l}\text { Labor-intensive } \\
\text { finished goods }\end{array}$} & \multicolumn{2}{l|}{$\begin{array}{l}\text { Capitaland technology-intensive } \\
\text { manufactured goods }\end{array}$} \\
\cline { 2 - 12 } & SITC0 & SITC1 & SITC2 & SITC3 & SITC4 & SITC6 & SITC8 & SITC5 & SITC7 & SITC9 \\
\hline 2007 & 0.17 & 0.05 & 0.02 & 0.28 & 0.26 & 1.13 & 0.73 & 0.38 & 0.71 & 0.00 \\
\hline 2008 & 0.09 & 0.03 & 0.02 & 0.23 & 0.27 & 1.16 & 0.52 & 0.54 & 0.79 & 0.00 \\
\hline 2009 & 0.12 & 0.04 & 0.01 & 0.19 & 0.16 & 1.36 & 0.66 & 0.38 & 0.89 & 0.00 \\
\hline 2010 & 0.12 & 0.04 & 0.01 & 0.15 & 0.11 & 1.45 & 0.57 & 0.44 & 0.75 & 0.01 \\
\hline 2011 & 0.09 & 0.03 & 0.01 & 0.13 & 0.11 & 1.47 & 0.60 & 0.47 & 0.73 & 0.02 \\
\hline 2012 & 0.09 & 0.03 & 0.02 & 0.13 & 0.12 & 1.16 & 0.79 & 0.44 & 0.70 & 0.01 \\
\hline 2013 & 0.09 & 0.03 & 0.02 & 0.13 & 0.12 & 1.34 & 0.61 & 0.46 & 0.72 & 0.01 \\
\hline 2014 & 0.10 & 0.04 & 0.02 & 0.14 & 0.17 & 1.40 & 0.61 & 0.51 & 0.63 & 0.02 \\
\hline 2015 & 0.10 & 0.04 & 0.02 & 0.17 & 0.17 & 1.38 & 0.59 & 0.50 & 0.63 & 0.02 \\
\hline 2016 & 0.12 & 0.04 & 0.02 & 0.20 & 0.14 & 1.36 & 0.60 & 0.50 & 0.61 & 0.03 \\
\hline
\end{tabular}




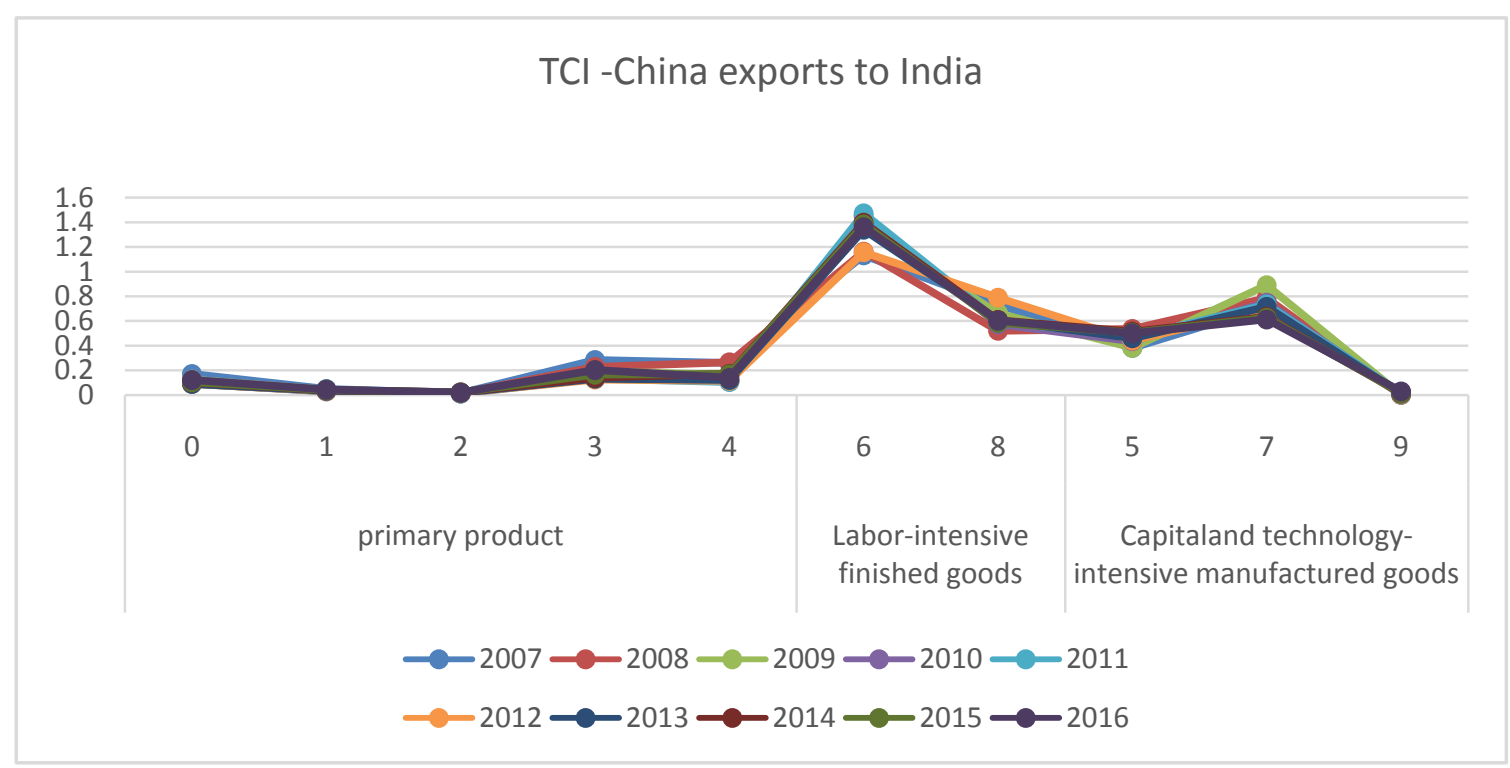

Fig4

When China, as an exporting country, is an importer, China's trade complementarity index on primary products SITC0-SITC4 is very weak. On the finished products, the trade complementarity index of China and India only on SITC6 is larger and their complementarity Degree is relatively strong. This shows that China has more exports on the finished product and happens to have a strong import demand on SITC6. Both parties are highly complementary. While in SITC5, SITC7, SITC8 index of trade complementarity is not large, but are basically in a slow growth trend, complementarity is rising, the trade structure in perfect.

Table 6 TCI -India exports to China

\begin{tabular}{|l|l|l|l|l|l|l|l|l|l|l|}
\hline \multirow{2}{*}{ year } & \multicolumn{4}{|l|}{ primary product } & \multicolumn{3}{l|}{$\begin{array}{l}\text { Labor-intensive } \\
\text { finished goods }\end{array}$} & \multicolumn{2}{l|}{$\begin{array}{l}\text { Capitaland technology-intensive } \\
\text { manufactured goods }\end{array}$} \\
\cline { 2 - 12 } & SITC0 & SITC1 & SITC2 & SITC3 & SITC4 & SITC6 & SITC8 & SITC5 & SITC7 & SITC9 \\
\hline 2007 & 0.36 & 0.08 & 7.25 & 1.06 & 1.17 & 1.54 & 1.09 & 1.12 & 0.36 & 0.02 \\
\hline 2008 & 0.38 & 0.13 & 7.84 & 0.98 & 1.04 & 0.83 & 0.96 & 1.09 & 0.46 & 0.03 \\
\hline 2009 & 0.25 & 0.14 & 6.59 & 0.95 & 0.92 & 1.67 & 1.13 & 0.88 & 0.54 & 0.05 \\
\hline 2010 & 0.32 & 0.13 & 6.33 & 1.11 & 0.79 & 1.60 & 0.84 & 0.94 & 0.48 & 0.10 \\
\hline 2011 & 0.37 & 0.12 & 4.58 & 1.14 & 0.66 & 1.27 & 0.84 & 0.92 & 0.48 & 0.49 \\
\hline 2012 & 0.52 & 0.15 & 5.59 & 1.20 & 0.69 & 1.22 & 0.92 & 1.02 & 0.47 & 0.14 \\
\hline 2013 & 0.57 & 0.14 & 4.30 & 1.28 & 0.63 & 1.25 & 0.70 & 1.00 & 0.46 & 0.42 \\
\hline 2014 & 0.60 & 0.13 & 3.71 & 1.78 & 0.53 & 1.34 & 0.71 & 1.00 & 0.50 & 0.15 \\
\hline 2015 & 0.58 & 0.14 & 4.69 & 1.39 & 0.60 & 0.92 & 0.71 & 0.96 & 0.54 & 0.21 \\
\hline 2016 & 0.51 & 0.15 & 3.86 & 1.51 & 0.61 & 0.90 & 0.72 & 1.01 & 0.36 & 0.15 \\
\hline
\end{tabular}




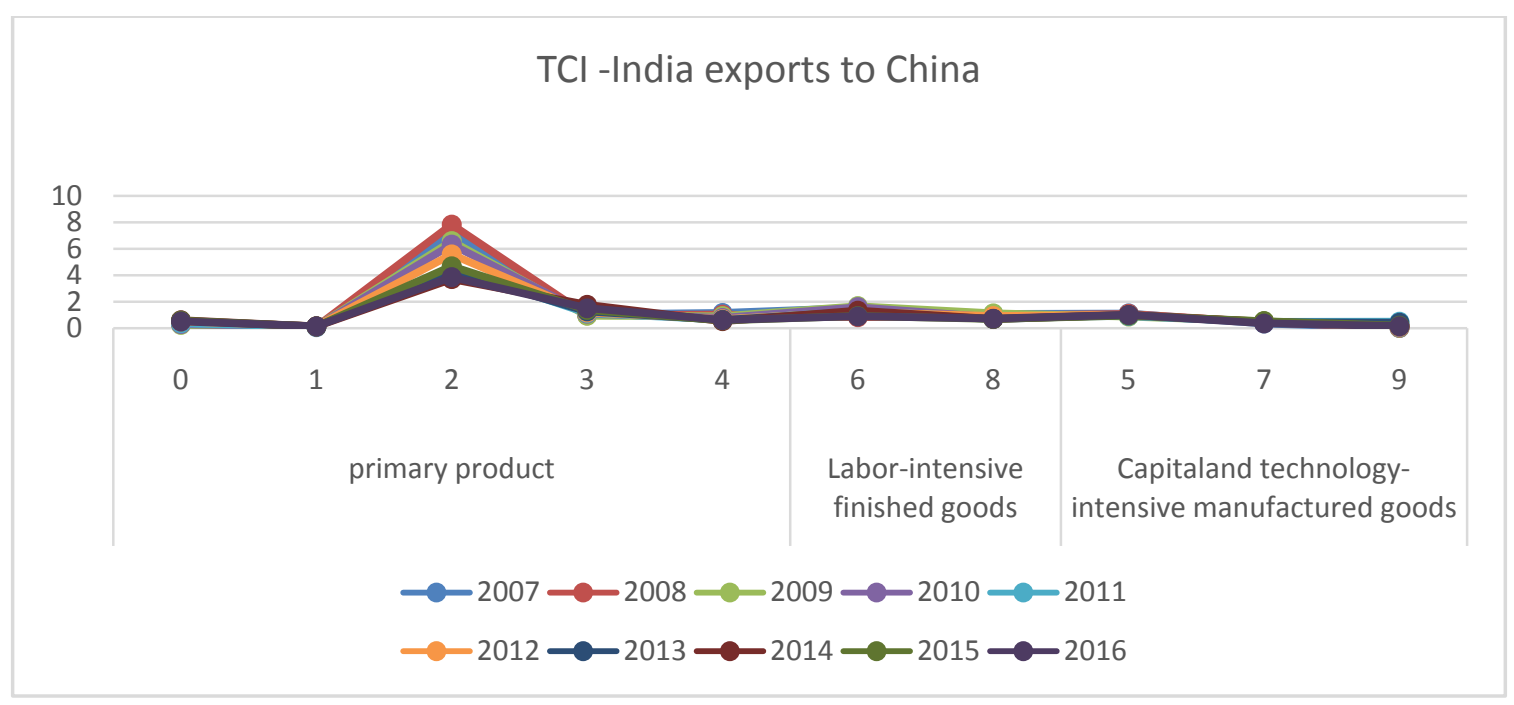

Fig5

The trade complementarity index of China, as an importing country, with India as exporter, shows that China and India are very complementary in the second category of products and the TCI index is very large with a peak of 7.84. However, from 2007 to 2016, the index is declining year by year and the degree of decline has been very clear, dropping from 7.25 in 2007 to 3.86 in 2016 . This shows that in the early India, SITC2 products exported very much and China imported a great demand. However, the declining index also shows that the trade between China and India in this product is declining. At the same time, the TCI indices of the primary products SITC3 and SITC4 are all around 1, indicating that the two countries are also more complementary in such products. On finished products, the TCI indices of SITC5, SITC6 and SITC8 are both around 1, indicating that the two countries are also highly complementary in finished products.

\section{Conclusion}

Overall, the trade complementarities between China and Russia and India outweigh the competitiveness. From the trend of the display comparative advantage index RCA and trade complementarity index TCI from 2007 to 2016, we can see that the advantage of our country on finished products is more obvious. Russia and India both have comparative advantages and competitiveness in the production of some primary products. And because of resource endowments, China is very complementary to Russia in 23 categories of products, indicating that China is highly dependent on Russia's mineral products and energy resources, and the degree of dependence is on the rise. On industrial products, China and Russia have strong complementarities between the two labor-intensive products, 6 and 8, and they are competitive with SITC5, a capital and technology-intensive product. The trade potential between China and Russia is huge and the trade scale needs to be further improved. China and India have strong complementarities only on products of the 2nd and 6th category, and are highly competitive on other products. In the bilateral trade between China and India, the two countries should continue to strengthen their trade in products with comparative advantages according to different resource endowments, such as exporting minerals from India and export of electromechanical products from China, making full use of the complementarities of bilateral trade. Judging from the historical track of trade between China and India, the total volume of import and export trade between the two countries has been constantly increasing, and the degree of trade integration has been continuously improved.

On a world scale, the economic and trade cooperation between China and India, Russia and elsewhere in the region is not balanced. China and Russia are all-round strategic partnership of cooperation; India is a strategic partnership for peace and prosperity and both sides are pushing ahead with free trade negotiations; and in the existing regional trading system, China and India, Russia and 
other countries have made great achievements in regional cooperation There is still great potential for development.

\section{Policy Suggestion}

Promote trade to diversify direction: Only through diversified trade can the cooperation between the two countries be deepened and comprehensively enhanced, and the stability of trade between the two countries will be even stronger. Relatively speaking, the trade type and structure between China and India and Russia are relatively simple, with some primary products such as energy and minerals. Therefore, promoting the development of trade in a deeper and broader direction is an inevitable trend. Russia is a big military power. China can step up its cooperation with Russia in the military field, enhance the procurement of military products and promote the development of military trade between China and Russia. It is also possible to vigorously develop the activities of the Cultural Festival and the Year of Culture of China, India and Russia, strengthen mutual understanding and cooperation in the field of culture, develop cultural products and promote the development of cultural trade. The implementation of export market diversification strategy can reduce the dependence on a single market, reduce market concentration and diversify risks.

Focus on scientific and technological innovation : Despite the large and competitive trade complementarity between China and the two countries, the competitiveness of the products of the countries concerned in the world market can not be ignored. Therefore, on the basis of the existing capital and technological advantages, China should pay attention to improving the capability of scientific research and innovation, developing new technologies, cultivating new leading industries, realizing differentiated development with all countries and enhancing trade complementarities with other countries. At present, the processing trade is the main form of China's foreign trade, but there are problems such as few core technologies, dependence on foreign technologies, low value-added products and rising labor costs. In response, China should make overall plans for its processing trade policies and promote a gradient transfer of processing trade to the Midwest. At the same time, China should encourage research and development in science and technology and increase the profitability and added value of processing trade.

Weaken trade barriers and promote trade liberalization: A fair and transparent market environment is the basis for the development of trade between countries. There are different levels of trade barriers in countries along the "Belt and Road", such as the existing customs clearance links and technical barriers to trade in Central Asia. Second, trade frictions between China and other countries along the routes have occurred from time to time. China launched many anti-dumping, countervailing and safeguard measures and other investigations. In the face of these problems, firstly, we can further reduce the trade barriers between the two sides, reduce the tariff level, simplify customs clearance procedures and speed up customs clearance. Secondly, we can improve the laws and regulations in related fields, standardize the bilateral trade order and ensure that investors Competition in a fair and free market environment; and finally accelerate the establishment of a free trade zone so as to provide a broader and more convenient platform for the development of foreign trade.

\section{References}

[1]Bi Yanru, Shi Bo. Calculation and Analysis of Trade Potential of China and Five Central Asian Countries - Trade Complementarity Index and Gravity Model [J] .Asia Pacific Economy, 2010 (3): 47-51.

[2]Li Yan. China-Russia trade complementarity and development strategies [J]. Foreign Trade and Economic Cooperation, 2013 (4): 37-38.

[3]Kwong Yau-tong. An Empirical Study on the Competitiveness and Complementarity of Sino-Russian Trade [J]. International Business Studies, 2011 (1): 41-48. 
[4]WANG Yajing, CHEN Fuqiao, Qilian Chun. Comparative Study on the International Competitiveness of Chinese and Indian Textile [J]. World Business Review, 2005 (4): 23-25.

[5]Ding Zhenhui. Comparative Advantage and Complementarity of Sino-Russian Trade [J]. Russia Central Asia Eastern Europe Market, 2010 (9): 43-49.

[6]Zhang Henglong, Zhou Yuancheng.Journal of Xinjiang Normal University, 2015,36 (4): 76-84.

[7]He Min, Zhang Ningning, Huang Zequn.Competitive and Complementary Analysis of China's Agricultural Products Trade along the Belt and Road [J]. Agricultural Economics, 2016 (11)

[8] Lv Hongfen, Yu Y. Study on the Competitiveness and Complementarity of China-Brazil Bilateral Trade [J] .International Trade Issues, 2011 (02).

[9] Rui Yuan, An Empirical Study on the Export Potential of China's EU Trade in Goods, D.Shandong University, 2016.

[10] Yun ZHENG, Comparative Advantage in China-EU Trade and Status of International Division of Labor, J. International Commerce. 05(2006) 9-13. 